\title{
EVALUATION OF INNOVATION ACTIVITIES IN METALLURGICAL ENTERPRISES IN THE CZECH REPUBLIC
}

\author{
${ }^{1}$ Jindra PETERKOVÁ, ${ }^{2}$ Katarzyna CZERNÁ, ${ }^{3}$ Pavla MACUROVÁ \\ ${ }_{1,2,3}$ VSB - Technical University of Ostrava, Faculty of Economics, Ostrava, Czech Republic, EU \\ 13indra.peterkova@vsb.cz, ${ }^{2}$ katarzyna.czerna@vsb.cz,.3pavla.macurova@vsb.cz
}

https://doi.org/10.37904/metal.2019.787

\begin{abstract}
Present conditions of highly competitive environment lead the owners and management of metallurgical enterprises to a strategic orientation on innovation, which is necessary for their durability and obtaining a significant market position. For efficient implementation of innovation activities, it is essential to compare with others and to look for ways to use the collected knowledge. The steel industry has its specifics of material and energy intensity, the metallurgical production itself is associated with environmental burdens, and metallurgical companies have to cope with the low competition. It is the implementation of innovation activities that leads to securing production at the high-tech level and thus ensuring the viability of metallurgical enterprises. The paper aims to evaluate innovation activities of innovative metallurgical companies based in the Czech Republic. According to the methodology of Eurostat in 2010, innovative enterprises are considered as innovating enterprises that introduced one of the following innovations, namely product, process, marketing and organizational. The valuation will be based on data available at the Statistical Office in the Czech Republic within section 24 according to the CZ-NACE classification. Innovation activities will primarily be evaluated by their subject character, the way of development and results of the implementation of technical innovations, the novelty of product innovations, the initiator of innovation activities including barriers limiting innovation activities. The results obtained will be compared with those in the manufacturing industry. Based on the results obtained, the knowledge base on innovation activities of metallurgical enterprises will be expanded.
\end{abstract}

Keywords: Innovation activities, technical innovations, non-technical innovations, obstacles for realization of innovations, metallurgical enterprises

\section{INTRODUCTIONS}

Manufacturing of basic metals, metallurgical and foundry industry /CZ-NACE 24/ is one of the most important manufacturing industries, accounting for $4.1 \%$ of total industry sales [1]. This field of the industry includes five groups. According to the volume of sales, the most important is the production of raw iron, steel, and ferroalloys, flat products, hot forming. The majority of metallurgical products are semi-finished products and products intended for further processing, which are further appreciated; roughly two-thirds of the production is directed to intermediate consumption. The production mainly appears in engineering, automotive and shipbuilding. CZ-NACE 24 provides material inputs in the form of metal semi-finished products for the CZNACE 25, which focuses on the production of metal structures and metal products. The result of the production is either final metal products or semi-finished products that enter processing in other sectors, especially in engineering, electrical engineering, construction and automotive. The aim of manufacturing companies in this sector is to increase the added value of their products through the continuing assembly of their metalworking products into engineering equipment and thus gain the character of engineering production.

CZ-NACE 24 and 25 are technologically linked. Within the used technologies, they are part of the MEDIUM LOW-TECH sector. Both industries are highly material and energy intensive, have extremely adverse environmental impacts and are associated with high risks in terms of occupational safety. Businesses also need to meet increasingly demanding legislative requirements for reducing environmental impact and energy intensity. Deepening labor shortages and growing customer demands for chemical composition and physical 
properties of metallurgical products play a significant role. These factors determine the necessity and focus of innovation activities of metallurgical enterprises to meet the demanding environment.

The paper aims to evaluate the innovation activities of enterprises in the CZ-NACE 24 and CZ-NACE 25. Evaluation is carried out based on statistical data on innovation activities for the monitored period 2014-2016 for the nature of innovation, type and method the development of process innovation, the result of the introduction of process innovation, the initiator of innovation activities and obstacles limiting innovation activities. The evaluation of innovation activities of enterprises in CZ NACE 24-25 will be compared with the processing industry, the results compared using cluster analysis, Ward's method with Euclidean distance.

\section{THEORETICAL AND METODOLOGICAL BASES}

Recently, innovation has proven to be the driving force behind the business [2]. Innovations take shape from minor partial improvements to radical changes. Incremental innovations are the result of an activity that we do better than our competitors. Radical innovation is a world novelty [3]. EU countries monitor innovations by a statistical sample survey based on the Oslo Manual 2005, which was prepared by the OECD. Based on this guide, innovations are divided into technical and non-technical innovations. Technical innovations include product, process innovation; non-technical innovations then marketing and organizational innovation.

When evaluating innovation activities, data from the Czech Statistical Office (www.czso.cz) are used to collect the harmonized Eurostat questionnaire for a single EU survey on innovation CIS 2016 (Community Innovation Survey 2016) for the reference period 2014-2016. The evaluation of innovation activities is carried out for innovative enterprises based in the Czech Republic operating in the manufacturing industry, especially for enterprises in the CZ-NACE 24, and CZ-NACE 25. Officially, the CZSO reports the results of the innovation survey altogether for both sectors. Separated data were provided on request. 1,337 enterprises participated in the statistical survey, of which 112 enterprises from CZ-NACE 24 and 1225 enterprises from CZ-NACE 25.

To compare the results for innovative enterprises in the CZ-NACE 24 and the manufacturing industry, hierarchical cluster analysis with Ward's technique and Euclidean distance will be used. Cluster analysis refers to a group of methods that aim to classify a set of objects into several relatively homogeneous subsets, designated as clusters, by analyzing multidimensional data. Objects inside clusters should be as similar as possible, and objects belonging to different clusters will be as different as possible. The essential criterion for creating object clusters is the similarity between objects. Similarity measurements can be made using an appropriate degree of correlation, distance measure, or association rate. Typical distances are Euclidean distance. Ward's method is useful for working with objects that have the same dimension of variables. Ward's minimum variance method is the most commonly used method in management [4-5]. The Ward's method calculates the increment of the sum of the squares of deviations generated by merging them at each step for all the pairs of deviations and then combines those clusters that correspond to the minimum value of that increment. A binary tree, dendrogram can represent clustering by this method.

\section{RESULTS}

Evaluation of innovation activities of enterprises belonging to CZ-NACE 24-25 is realized based on data of the Czech Statistical Office including manufacturing industry concerning selected criteria and at the same time through cluster analysis focusing on identifying differences.

\subsection{Evaluation of innovation activities based on CZSO data}

Data analysis according to the CZSO for the period 2014-2016 shows that enterprises engaged in the production of basic metals, metallurgical metal processing and foundry $/ 24 /$ innovated more intensively (56 \%) than enterprises engaged in the manufacture of metal structures and metal products /25/ (49\%). Enterprises in both sectors $/ 24,25 /$ only made more intensive technical innovations than non-technical innovations. and innovated less (50\%) than total manufacturing (52\%), see Figure 1. 


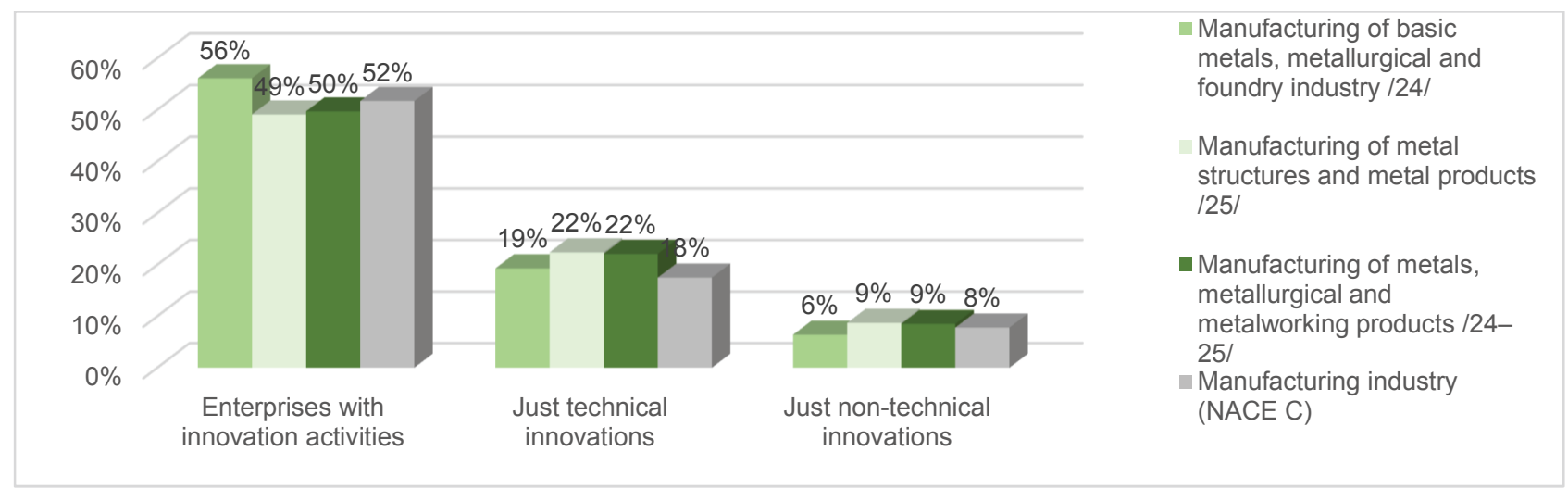

Figure 1 Share of innovating / non-innovative and technological/ non-technological innovating enterprises in the total number of enterprises, source: CZSO data

Enterprises in both sectors $/ 24,25 /$ realize, within the framework of technical innovations, only process innovation rather than product innovation. In the framework of non-technical innovations, they implement more often only marketing innovations than just organizational innovations. The results see Figure 2. To illustrate the nature of the latest product innovations, adjustment of pipe for horizontal drilling for shale extraction or the use of microalloying for the production of smaller diameter, thinner walls and smaller weight pipes such as racks or retaining systems can be mention [6]. Product innovations generally require the adaptation of technology. These statistics do not capture cases of the interconnection of both types of innovation. Innovated products or services in both sectors /24-25/ were more often new for the enterprise than the whole market.

\begin{tabular}{|c|c|c|c|c|}
\hline $20 \%$ & $\begin{array}{l}\text { Manufacturing of basic metals, } \\
\text { metallurgical and foundry } \\
\text { industry } / 24 /\end{array}$ \\
Manufacturing of metal \\
structures and metal products \\
$/ 25 /$
\end{tabular}

Figure 2 Share of innovative enterprises with a particular type of innovation activity in the total number of enterprises, source: CZSO data

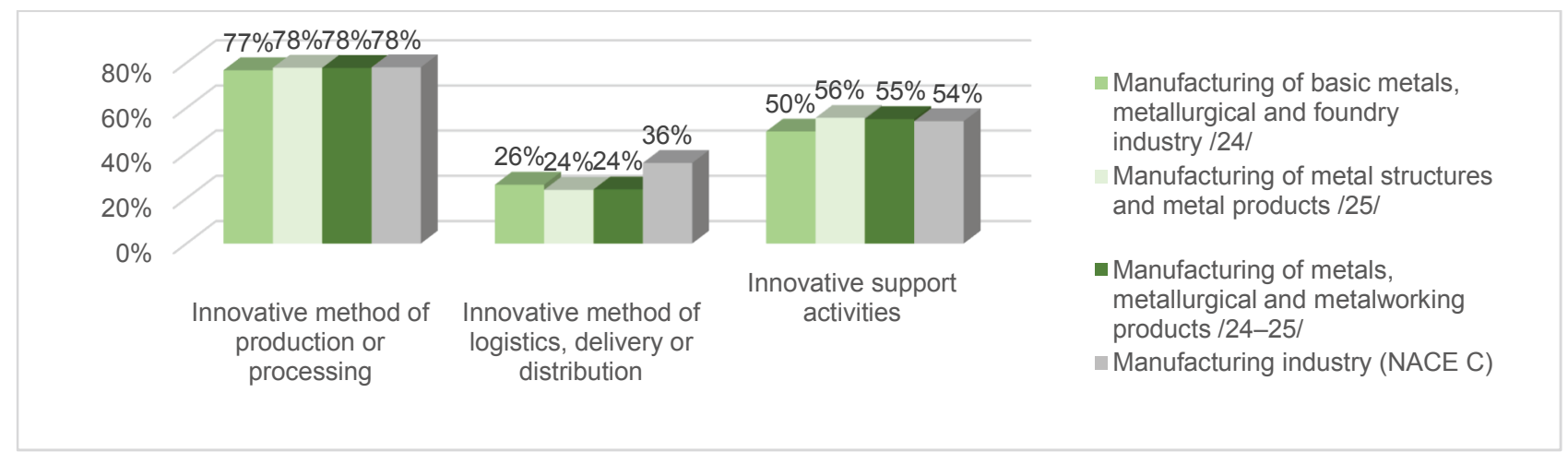

Figure 3 The share of innovating enterprises concerning the established type of process innovation on the total number of process innovation enterprises, source: CZSO data 
Enterprises in the sectors $/ 24,25 /$ most intensively implement an innovative method of manufacturing or processing within process innovation. On the contrary, they are least concerned with innovations in logistics, supply or distribution methods. Compared to the manufacturing industry, the difference is the most in innovations of logistics, supply or distribution methods, where enterprises in sectors $124,25 /$ are little concerned with innovation of this type, see Figure 3.

Enterprises in the branches $/ 24,25 /$ including the manufacturing industry are implementing most intensively self-managed innovations, see Table 1. Another way to develop innovative processes in enterprises in the /24/ sector is to work with entities within a corporate group and collaborate with entities outside the corporate group. For enterprises in the sector $/ 25 /$, the second way is to develop innovative processes in collaboration with companies outside the corporate group and adopt the process developed by another entity. At the same time, $15 \%$ of innovating enterprises in the sector $/ 24 /$, respectively $2 \%$ of the sector $/ 25 /$, develop innovation in collaboration with universities or research institutions. Universities or research institutions developed no innovation on an assignment from companies.

Table 1 The share of innovating enterprises with regard to the way of development of innovated processes on the total number of process innovation enterprises

\begin{tabular}{|c|c|c|c|c|c|c|c|}
\hline CZ-NACE sector & $\begin{array}{c}\text { Self- } \\
\text { managed }\end{array}$ & $\begin{array}{c}\text { Cooperation } \\
\text { with } \\
\text { enterprises } \\
\text { within a } \\
\text { corporate } \\
\text { group }\end{array}$ & $\begin{array}{c}\text { Cooperation } \\
\text { with } \\
\text { enterprises } \\
\text { outside a } \\
\text { corporate } \\
\text { group }\end{array}$ & $\begin{array}{c}\text { Cooperation } \\
\text { with } \\
\text { universities } \\
\text { or research } \\
\text { institutions }\end{array}$ & $\begin{array}{c}\text { Adaptation } \\
\text { of process } \\
\text { developed } \\
\text { by another } \\
\text { entity }\end{array}$ & $\begin{array}{c}\text { Assignment } \\
\text { to other } \\
\text { companies } \\
\text { /within a } \\
\text { corporate } \\
\text { group }\end{array}$ & $\begin{array}{c}\text { Assignment } \\
\text { to } \\
\text { universities } \\
\text { or research } \\
\text { institutions }\end{array}$ \\
\hline $\begin{array}{c}\text { Manufacturing of basic } \\
\text { metals, metallurgical and } \\
\text { foundry industry /24/ }\end{array}$ & $54 \%$ & $25 \%$ & $19 \%$ & $15 \%$ & $17 \%$ & $7 \%$ & $0 \%$ \\
\hline $\begin{array}{c}\text { Manufacturing of metal } \\
\text { structures and metal } \\
\text { products /25/ }\end{array}$ & $77 \%$ & $6 \%$ & $12 \%$ & $2 \%$ & $11 \%$ & $6 \%$ & $0 \%$ \\
\hline $\begin{array}{c}\text { Manufacturing of metals, } \\
\text { metallurgical and } \\
\text { metalworking products /24- } \\
\text { 25/ }\end{array}$ & $75 \%$ & $8 \%$ & $12 \%$ & $3 \%$ & $11 \%$ & $6 \%$ & $0 \%$ \\
\hline $\begin{array}{c}\text { Manufacturing industry } \\
\text { (NACE C) }\end{array}$ & $71 \%$ & $16 \%$ & $17 \%$ & $6 \%$ & $11 \%$ & $7 \%$ & $1 \%$ \\
\hline
\end{tabular}

Source: CZSO

The upturned process innovation for enterprises in the /24/ sector is related to increasing the quality of the product, followed by the expansion of production capacity and increased production flexibility, the way the services are delivered. For enterprises in the sector $/ 25 /$, the established process innovation focuses primarily on increasing production flexibility and service delivery, expanding production capacity and improving product quality. In manufacturing, the established process of innovation involves increasing production flexibility, service delivery. The share of enterprises in $/ 24 /$, which introduced innovations leading to the reduction of health and safety risks of employees (13\%), is significant, compared to /25/ $(2 \%)$ and manufacturing (3\%). Examples of realized process innovations in metallurgical enterprises of the Czech Republic include: environmental projects focused on dedusting operation, reducing noise, reducing energy consumption [7]; introduction of automation in production and production control eg robotic extrusion of hot slabs for rolling mills, computer-controlled unmanned guide, extrusion and extinguishing cars in coke oven, digital twins for simulation and control of blast furnace operation, introduction of sensors for predictive maintenance interconnection of information systems with customers. Some companies set up separate organizational units equipped with development workers to implement automation [8]. 
The main initiator in the implementation of innovation activities is in the branch $/ 24 /(90 \%)$, also in the branch /25/ (94\%) including manufacturing industry (91\%) the management of the enterprise. For enterprises in the sector $/ 24 /$ second place are the customers or consumers (57\%), then the parent company or other enterprises in the group (34 \%). Enterprises in the sector / 25 / in second place are again customers or consumers of the production of the enterprise $(27 \%)$ and third place ordinary employees $(19 \%)$. On the other hand, in the case of enterprises in the sector (24-25) and manufacturing industry, the suppliers of the company initiate the least. Statistics do not consider the owner as the initiator of innovation activities. The main obstacle to reducing innovation activities is the shortage of skilled workers, namely for enterprises in the sector $/ 24 /(40 \%)$, in the sector $/ 25 /(35 \%)$, also in manufacturing industry (37\%). Another significant obstacle is the lack of funding and difficulties in obtaining public support for innovation activities for enterprises in the sector /24/ and in manufacturing industry. For enterprises in the sector $/ 25 /$, the ranking reverses, the major obstacle is the difficulty in obtaining public support for innovation activities and then the lack of funding.

\subsection{Comparison of results through cluster analysis}

Hierarchical clustering analysis, Ward's technique with Euclidian distance was used to perform cluster analysis and two clusters of companies (dendrogram in Figure 4) were created. These was based on criteria: the share of innovative / non-innovative and technical / non-technical innovating enterprises in the total number of enterprises, the share of innovating enterprises with a certain kind of innovation activity in the total number of enterprises, the share of innovating enterprises with regard to the results of the introduction of process innovation on the total number of process innovating enterprises, the share of innovating enterprises with regard to the results of the introduction of process innovation on the total number of process innovation enterprises.

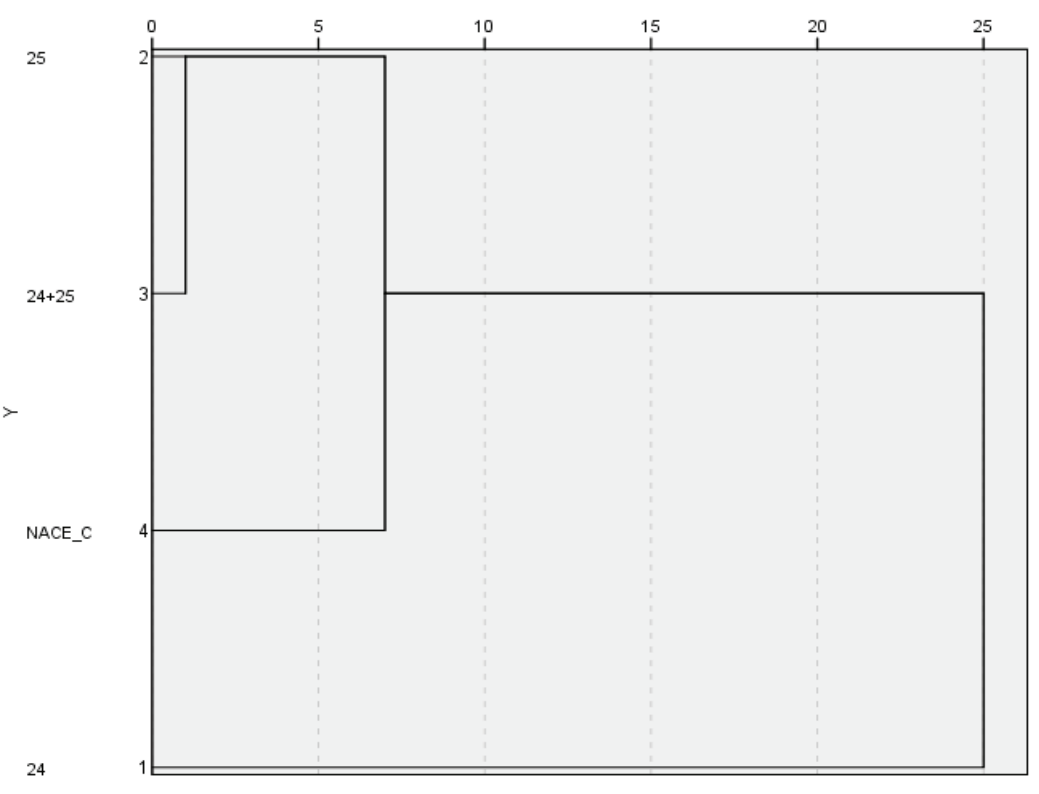

Figure 4 Dendrogram

The first cluster formed by enterprises in branches /24-25/, in the branch /25/ and in manufacturing industry (CZ-NACE C). Enterprises are linked in the way in which innovative processes are developed, less cooperation with universities and research institutions, and the results of implementing process innovations. The second cluster is made up of only enterprises in the sector $/ 24 /$. These companies are more likely to be more successful in reducing health and safety risks and rely more on parent companies or other businesses in the corporate group to initiate innovation activities. 


\section{CONCLUSION AND DISCUSSION}

The results of the statistical survey on the frequency and nature of innovations carried out in the metallurgical enterprises of the Czech Republic in 2014 - 2016, as well as on the areas of benefits and barriers to innovation activities, correspond to the characteristics of the examined sectors. It is somewhat precarious that out of the total number of enterprises in the metallurgical industries under investigation, only $50 \%$ of enterprises can be classified as innovative. For the years 2017 - 2018, the results of the CZSO statistical survey have not yet been published. It would be favorable if it turned out that the share of innovating enterprises in these sectors increased. On the other hand, it has to be taken into account that most of these actions are longer term and that innovation cycles have specific patterns. In some enterprises, innovation may have been underway in the years under review but has not been completed in the final period. For the next period, tightening of EU requirements for the use of best available techniques (BREF - Reference Document on Best Available Technique, BAT - Best Available Techniques) is expected to reduce emission and increase energy efficiency. Customers' demands for high-strength steel and surface quality will grow [9].

It is expected [10] that excess production capacity will deepen with the opening of new smelters in countries such as India and Iran. Further complications for the metallurgical industry may be the expected decline in demand due to the stagnation of the growth rate of economies in Europe and the impending introduction of tariffs for car deliveries from Europe to the US. Also, the trend that working in a hazardous environment will discourage job seekers may increase. Continuing automation in steelworks is, therefore, a must. However, as experts point out [8], the possible range of robots in the steelworks is limited to the complexity of some of the processes that robots cannot handle. Social service must also be in automated workplaces if there is any nonstandard situation. Companies that will not be able to cope with these more challenging conditions may be at risk. The urge for coherent planning and implementation of innovations in the steelworks is increasing.

\section{ACKNOWLEDGEMENTS}

This article was created with the financial support of the Student Grant Competition EkF, VŠB-TU Ostrava within project SP2019/47 " Evaluation of Innovation Activities and Identification of problems in Innovation Process in Selected Czech and Polish Enterprises". https://www.ekf.vsb.cz/projekty/cs/sgs/projekty-sgs/?projectDetailld=44897

\section{REFERENCES}

[1] MINISTERSTVO PRŮMYSLU A OBCHODU. Finanční analýza podnikové sféry za 1. pololetí 2018 [online]. Version 1. Last updated 12 April 2019. Praha: MPO. [viewed 2019-05-01]. Available from: https://www.mpo.cz/assets/cz/rozcestnik/analyticke-materialy-a-statistiky/analytickematerialy/2019/4/FA2Q2018.pdf

[2] VEBER, J. Management inovací. 1st Edition. Praha: Management Press, 2016. 289 p.

[3] TIDD, J.and BESSANT, J. Managing Innovation: Integrating Technological, Market and Organizational Change. 5th Edition. Chichester: Wiley, 2013. 680 p.

[4] CHARRY, K., COUSSEMENT, K., DEMOULIN, N. and HEUNVICK, N. The Ward's minimum variance method is the most commonly used method in management. In: Marketing Research with IBM SPSS Statistics. 2016. pp. 71.

[5] ŘEZÁNKOVÁ, H., HÚSEK, D. and SNÁŠEL V. Shluková analýza dat. Praha: Professional Publishing, 2009. 2nd Edition. 218 p.

[6] TELÚCH, T. Americká cla nám sebrala rostoucí trh s trubkami pro těžbu ropy a plynu. Portál Ocelářské unie ČR. [online]. Version 1. Last updated: 18. 10. 2018. Praha: Ocelářská unie [viewed 2019-04-30]. Available from: https://www.ocelarskaunie.cz/tomas-teluch-cast-americka-cla-nam-sebrala-rostouci-trh-s-trubkami-pro-tezburopyl 
[7] OU2. Oceláři letos investují do modernizace miliardy korun. Portál Ocelářské unie ČR. [online]. [viewed 2019-0430]. Available from: https://www.ocelarskaunie.cz/investice 2018/?highlight=ocel\%C3\%A1\%C5\%99i\%20letos\%20investuj\%C3\%AD\%20do\%20modernizace $\% 20$ miliardy $\% 20$ korun

[8] KUBÁT, V. Těžký průmysl 4.0: ArcelorMittal v Ostravě investuje do automatizace. Hospodářské noviny. [online]. Version 1, Last updated: 27 April 2017. Praha: Mafra [viewed 2019-04-30] Available from: https://archiv.ihned.cz/c1-65710010-tezky-prumysl-4-0-arcelormittal-v-ostrave-investuje-do-automatizace.

[9] CZUDEK, J. Část primární výroby oceli v Česku zřejmě zanikne. Portál Ocelářské unie ČR. [online]. Version 1. Last updated: 23 August 2018. Praha: Ocelářská unie [viewed 2019-0430] Available from: https://www.ocelarskaunie.cz/?s=\%C4\%8C \%C3\%A1st+prim $\% \mathrm{C} 3 \% \mathrm{~A} 1 \mathrm{rn} \% \mathrm{C} 3 \% \mathrm{AD}+\mathrm{v} \% \mathrm{C} 3 \% \mathrm{BDroby}+\mathrm{oceli}+\mathrm{v}+\% \mathrm{C} 4$ \%8Cesku+z\%C5\%99ejm\%C4\%9B+zanikne

[10] OU1. Nadměrné ocelářské kapacity ve světě. Portál Ocelářské unie ČR [online]. Version 1. Last updated: 4 June 2018. Praha: Ocelářská unie [viewed 2019-04-30]. Available from: https://www.ocelarskaunie.cz/nadmerneocelarske-kapacity-ve-svete/ 